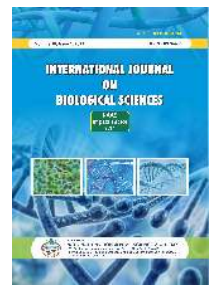

\title{
A RAPID SURVEY OF AVIFAUNAL DIVERSITY IN AND AROUND SANKEY TANK, BENGALURU
}

\author{
Dakshin V. John and M. Jayashankar* \\ St. Joseph's College (Autonomous) \\ Bengaluru-560 027, Karnataka
}

\section{Research Paper}

Received: 05.06.2020

Revised: 15.06.2020

Accepted: 29.06.2020

\begin{abstract}
Sankey Tank is located in the western part of Bengaluru near Malleshwaram and Sadashivanagar. Urbanization is a cause for the decline of species of birds in the city and certain places such as Sankey Tank. Thirty five species of birds were identified, 21 species were terrestrial birds and 14 species were waterbirds. The total species counts of terrestrial birds were 271 in number and the total counts of the waterbird species were 73 in number, adding up to a total 344 species counts. The counts of the House Crow and Blue rock Pigeon was explained and how best to control their population.
\end{abstract}

Keywords: Sankey Tank, hotspot, avifauna, house crow, rock pigeon.

\section{INTRODUCTION}

The world is urbanizing rapidly, and it is predicted that by $2050,66 \%$ of the global human population will be living in urban areas(https://www.un.org/ development/desa/en/ news/population/2018-revision-of-world-urbanizationprospects.html). Urbanization is characterised by landuse changes such as increased residential housing, business and development and transport infrastructure, resulting in habitat loss and fragmentation (James et al, 2019).Isaksson (2018) said that urban habitats and landscapes are markedly different from nonurban "natural" habitats. The major difference is the transformation of the land, from natural green areas to anthropogenic structures and impervious surfaces. To survive in the urban habitat, birds are forced to either accept or avoid the new conditions (Chace and Walsh, 2006). Isaksson (2018)also stated that today, urbanization is a global phenomenon with implications for birds as well as for all other animals. Yet, developing countries are still in the early phases of industrial revolution; thus, the impact of global urbanization is expected to increase.
Morrison (1986) and Koskimies (1989) found that birds, one of the most important indicators of the health of an ecosystem, react very rapidly to changes in their habitats. Decline in the density and number of bird species have been correlated with habitat loss and fragmentation. Although, these changes in the habitat are the main cause of species decline, the mechanisms causing fragmentation and the spatial distribution of resources act at different scales (Flather and Sauer, 1996). Christian (2015) reported that biodiversity hotspots, despite some criticism, have become a tool for setting conservation priorities and play an important role in decision-making for cost-effective strategies to preserve biodiversity in terrestrial and to some extent, marine ecosystems. This area-based approach can be applied to any geographical scale and it is considered to be one of the best approaches for maintaining a large proportion of the world's biological diversity. The present study area is facing urbanisation pressure which could impact the avian diversity it harbours. Hence, a rapid survey to record the species found in the area was undertaken.

*Corresponding author: jay81zoology@gmail.com 


\section{MATERIALSAND METHODS}

STUDY SITE: Sankey tank is located in Bengalurucity $\left(13.01^{\circ} \mathrm{N} 77.57^{\circ} \mathrm{E}\right)$ figure 1 in between Malleshwaram and Sadashivanagar. At its widest, the tank has a width of $2624.7 \mathrm{ft}(800 \mathrm{~m})$ and the lake covers an area is about 15 ha(roughly 37.1 acres) (The Hindu, 2003). It is a freshwater lake with its primary inflow being rainfall. Having a catchment area of 1.254 kms and a max depth of $9.26 \mathrm{~m}(30.4 \mathrm{ft})$, it is one of the large urban hotspots for many birds in the city. Sankey tank has a rich historical background being first named as "Gandhadhakotikere" in reference to the Govt Sandalwood depot that was located close by to the lake. Sankey tank was constructed by Col. Richard Hieram Sankey (The corps of Royal Engineers, RE) of the Madras Sappers Regiment, in 1882, to meet the water supply demands of Bangalore andwas linked to the Miller's tank and Dharmambudhi tank and was built as a safe guard against water shortages, such as that experienced in the Great Famine of 1876-1878(Hasan, 1970;Patrao,2003).

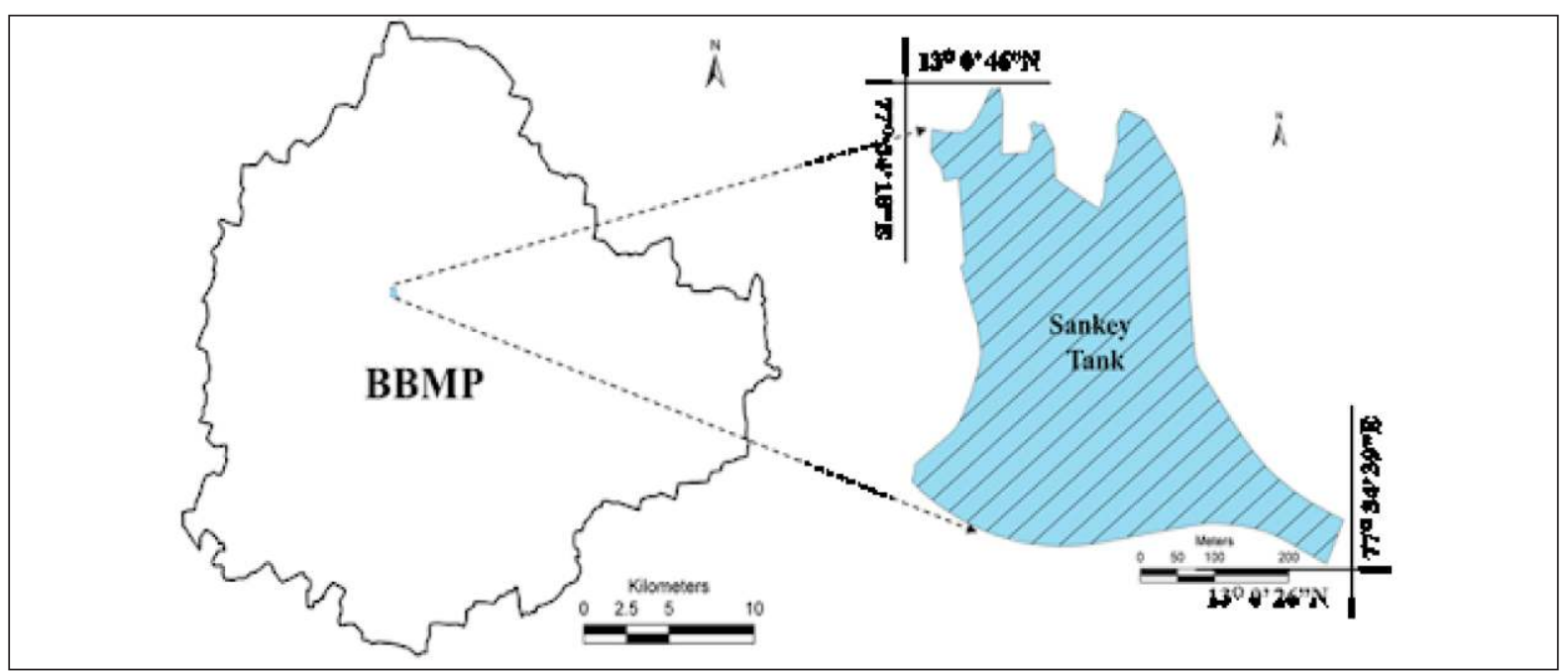

Fig. 1: Map of Bengaluru city with Sankey tank.

Methodology: Owing to the site condition, point count survey method (Hamel et al. 1996) was used. At certain parts of the lake, birds were monitored and surveyed using line transect (500 mts in 15 mins) methods (Rajashekara and Venkatesha 2019). The species were recorded through visual observation and then later classified into their respective families based on their description. Observations were made in the evenings between $4: 00 \mathrm{pm}$ to $6: 00 \mathrm{pm}$ which is the time during which the birds are most active. The species were identified and classified with the help of a field guide (Grimmet et al., 1998).Analysis of bird counts excluded records of birds in flight, to avoid data replication and misinterpretation of habitat usage; Species were grouped into waterbirds and terrestrial birds(Mancini et al. 2018).Binoculars for observation and reference books on birds, survey data sheets, pencil, eraser and field tools were also used for recording birds (Tobgay, 2018).

\section{RESULTS AND DISCUSSION}

A total of thirty species of avifauna were identified in Sankey tank, twenty one of which were terrestrial birds and 14 categorised as water bird(table 1 , figure 1 ). The total species counts of terrestrial birds were 271 in number and the total counts of the waterbird species were 73 in number adding up to a total 344 species counts of terrestrial and waterbirds. All the species observed belong to the "Least concern(LC) category (IUCN, 2019). From the number of species counts from data in the tabular column, it is clear that Sankey tank harbours numerous avifaunal species. Some findings of the data that need to be looked upon are the high increase of the House crow species and the alarming number of Blue rock Pigeons. The Hindu (2018) reported that the Kalyani (pond) in Sankey Tank has turned into the city's own Trafalgar Square, with hundreds of pigeons flocking the place every day. While it looks picturesque, especially when the birds take wing together, some regular walkers are 
apprehensive about their presence. According to Ornithologist M.B. Krishna "Pigeons are quite harmless, though a nuisance at time and reports about them spreading disease are not proven. Cross-species infection is not as prevalent as some people make it out to be". He is of the opinion that buildings in urban areas if designed to have sloping ledges and not flat ones, the pigeon population can be controlled. Pigeons are capable of breeding rapidly in the presence of abundant food, therefore a long-term solution for managing this urban pest species should not rely simply on eradicating or culling(Outerbridge, 2016). Also, considering the fact that pigeon feeding is largely a religious practice, wherein people believe that it is akin to doing good deed and will bring prosperity (The Hindu, 2018). This goes to show that in order to control the population of the pigeons, the limiting of food resources is a critical component. As for the increasing crow population according to Ilana (2014) crows' negative reputation as nest predators is largely underserved. Yes, crows do feed on songbird eggs. But studies have shown that crows play a relatively small role in nest predation. The main predator being squirrels and snakes. Then raccoons and possums, birds are last in the list,viz., jays, raptors, cowbirds and mics. Crows are way down on the list. It is clear from the findings that the large number of House crow species and the Blue rock Pigeon species are harmless and can be controlled by the limitation of food resources. Ilana (2014) passionately states that "The best thing is to change your attitude. Those crows in your yard aren't a mob. They're not a gang. They're probably a family. And they're very beautiful if you look at them”.

From the present data it is evident that the environ of Sankey tank can house many different species of avifauna and vegetation to support this. There is a need for conservation and safeguarding of Sankey tank as it is one of the few "Urban Biodiversity Hotspots" in Bengaluru.

Table 1: Avifauna observed in the study area.

\begin{tabular}{|c|c|c|c|c|}
\hline & \multicolumn{2}{|c|}{ Terrestrial birds } & \multicolumn{2}{|r|}{ Water birds } \\
\hline $\begin{array}{l}\text { Sl } \\
\text { No. }\end{array}$ & $\begin{array}{l}\text { Common } \\
\text { name }\end{array}$ & Scientific name & $\begin{array}{l}\text { Common } \\
\text { name }\end{array}$ & Scientific name \\
\hline 1 & Black kite & Milvis migrans & $\begin{array}{l}\text { Greater } \\
\text { Coromorant }\end{array}$ & Phalacrocorax carbo \\
\hline 2 & $\begin{array}{l}\text { Blue rock } \\
\text { pigeon }\end{array}$ & Columba livia & $\begin{array}{l}\text { Little } \\
\text { Cormorant }\end{array}$ & Phalacrocorax niger \\
\hline 3 & House crow & Corvuss plendens & Little Egret & Egretta garzetta \\
\hline 4 & Jungle crow & Corvus macrorhynchos & Muscovy Duck & Cairina moschatta \\
\hline 5 & Common myna & Acridotheres tristis & Mallard & Anas platyrhynchos \\
\hline 6 & $\begin{array}{l}\text { Rose-Ringed } \\
\text { parakeet }\end{array}$ & Psittacula krameri & $\begin{array}{l}\text { Indian } \\
\text { Cormorant }\end{array}$ & Phalacrocorax fuscicollis \\
\hline 7 & $\begin{array}{l}\text { Purple rumped } \\
\text { sunbird }\end{array}$ & Nectarinia asiatica & $\begin{array}{l}\text { Indian pond } \\
\text { Heron }\end{array}$ & Ardeola grayii \\
\hline 8 & Spotted owlet & Athene brama & $\begin{array}{l}\text { Domestic } \\
\text { goose }\end{array}$ & Anser sp. \\
\hline 9 & $\begin{array}{l}\text { Greater coucal } \\
\text { barbet }\end{array}$ & Centropus sinensis & $\begin{array}{l}\text { Grey-headed } \\
\text { Swamphen }\end{array}$ & Porphyrio poliocephalus \\
\hline 10 & White cheeked & Megalamia virdis & $\begin{array}{l}\text { Black-crowned } \\
\text { Night-Heron }\end{array}$ & Nycticorax nycticor \\
\hline 11 & Brahminy kite & Haliastur indus & Cattle Egret & Bubulcus ibis \\
\hline
\end{tabular}




\begin{tabular}{|l|l|l|l|l|}
\hline 12 & $\begin{array}{l}\text { Large pied } \\
\text { wagtail }\end{array}$ & Motacilla maderaspatenis & $\begin{array}{l}\text { Intermediate } \\
\text { Egret }\end{array}$ & Ardea intermedia \\
\hline 13 & $\begin{array}{l}\text { Tickell's } \\
\text { Flowerpecker }\end{array}$ & Dicaem erythrorhynchos & Eurasian Coot & Fulica atra \\
\hline 14 & $\begin{array}{l}\text { Blyth's Reed- } \\
\text { Warbler }\end{array}$ & Acroephalus dumetorum & $\begin{array}{l}\text { Purple } \\
\text { Moorhen }\end{array}$ & Porphyrio porphyrio \\
\hline 15 & $\begin{array}{l}\text { White-Breasted } \\
\text { Kingfisher }\end{array}$ & $\begin{array}{l}\text { Halcyon } \\
\text { smyrnensis }\end{array}$ & & \\
\hline 16 & Ashy prinia & Prinia socialis & & \\
\hline 17 & $\begin{array}{l}\text { Red whiskered } \\
\text { Bulbul }\end{array}$ & Pycnonotus joscsus & & \\
\hline 18 & Black drongo & Dicrurus macrocercus & & \\
\hline 19 & $\begin{array}{l}\text { Greenish } \\
\text { Warbler }\end{array}$ & Phylloscopus trochiloider & & \\
\hline 20 & $\begin{array}{l}\text { Red-vented } \\
\text { Bulbul }\end{array}$ & Pycnonotus cafer & & \\
\hline 21 & $\begin{array}{l}\text { Coppersmith } \\
\text { Barbet }\end{array}$ & Psilopogon haemacephalus & & \\
\hline
\end{tabular}

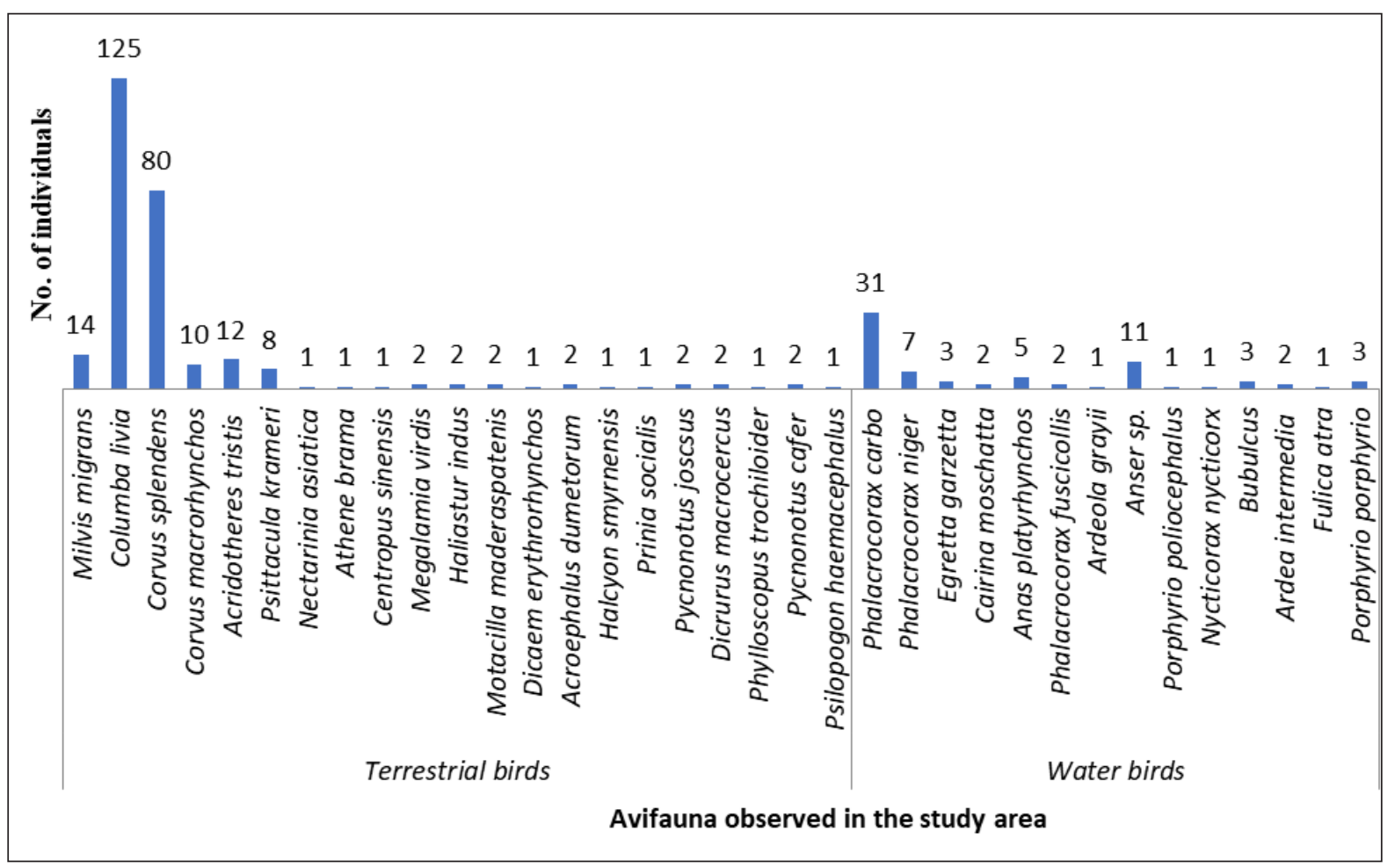

Fig. 1: Number of individuals of each species observed 


\section{REFERENCES}

1. Chace, J and Walsh, J. (2006). Urban effects on native avifauna: A review. Landscape and Urban Planning. 74. 46-69. 10.1016/j. landurbplan. 2004.08.007.

2. Chandra, K. and Singh, R.K. (2004). Avifauna of Madhya Pradesh and Chattisgarh. Zoos' Print.

3. Christian M (2015),"Biodiversity hotspots: A shortcut for a more complicated concept”, Global Ecology and conservation. 3: 297-309.

4. Gibbons, D.W. and Gregory, R.D. (2006). Birds: Ecological Census Techniques, Royal Society.

5. Flather, C.H. and J.R. Sauer. (1996). Using landscape ecology to test hypotheses about largescale abundance patterns in migratory birds. Ecology, vol.77, no.1, 1996, pp. 28-35. JSTOR, www.jstor.org/stable/2265651. Accessed 29 Nov. 2020. DOI: $10.2307 / 2265651$.

6. Hamel, P.B., Smith, W.P., Twedt, D.J., Woehr, J.R., Morris, J.R.and Hamilton, R.B. (1996). A Hasan, M F (1970). Bangalore through the centuries. Historical Publications. pp. 185-186.

7. Ilana DeBare (2014), “Counting Crows: Why are these so many?” Crows staging in a tree after sunset.

8. Isaksson C. (2018) Impact of Urbanization on Birds. In: Tietze D. (eds) Bird Species. Fascinating Life Sciences. Springer, Cham. https://doi.org/10.1007/978-3-319-91689-7_13.

9. IUCN (2019).The IUCN Red List of Threatened Species. Version 2019-2. http://www. iucnredlist.org. Downloaded on 20 November 2019.

10. James R, S., Ibáñez-Álamo, J.D., Sumasgutner, P and Mark C. Mainwaring (2019)." Urbanisation and nest building in birds: a review of threats and opportunities”. J Ornithol 160, 841-860. https://doi.org/10.1007/s10336-01901657-8.

11. Koskimies, P. (1989). Birds as a tool in environmental monitoring. Annales Zoologici
Fennici, 26(3): 153-166. Retrieved November 13, 2020, fromhttp://www.jstor.org/stable/23734578.

12. Mancini, $\mathbf{P}$ L, Armando S. Reis-Neto, Luciano G F, Luís F S and Yara Schaeffer-Novelli. (2018). Differences in diversity and habitat use ofavifauna in distinct mangrove areas in São Sebastião, São Paulo, Brazil, Ocean \&Coastal Management,164: 79-91, https://doi.org/ 10.1016/j.ocecoaman.2018.02.002.

13. Morrison M.L. (1986) Bird Populations as Indicators of Environmental Change. In: Johnston R.F. (eds) Current Ornithology. Current Ornithology, 3. Springer, Boston, MA. https://doi.org/10.1007/978-1-4615-6784-4_10

14. Outerbridge, M.E. (2016). Feral Pigeon (Columba liviadomestica) Management Plan for Bermuda. Department of Environment and Natural Resources, Government of Bermuda. 29 pages.

15. Patrao, M (2013). "When parks were a lark" (Bangalore). Deccan Herald. Retrieved 20 January 2015.

16. Grimmett, R., Inskipp, C., andInskipp, T., (1998). Birds of the Indian Subcontinent. 1st ed. London: Christopher Helm, A \& C Black. Pp. 1-888.

17. Rajashekara S., and Venkatesha, M.G. (2019). Additions to the Birds of Bangalore University Campus (BUC), India. Proc Zool Soc. 72: 197. https://doi.org/10.1007/s12595-017-0231-1

18. The Hindu. (2003). Archived from the original on 4 May 2003. Retrieved 2 October 2006.

19. The Hindu (2018).”Walkers uneasy as pigeon numbers grow around Sankey Tank" (Updated March 25, 2018 09:05 IST).

20. Tobgay, S. (2018).Bird diversity and distribution.10.13140/RG.2.2.19808.58881.(http s://www.researchgate.net/publication/32428016 1_Bird_diversity_and_distribution). 